\title{
39. 治療ビームを用いての照射野確認の陚为
}

\author{
An experimental study of treatment verification using high \\ energy photon beam images
}

大阪府立羽电野病院放射線科 ○藤岡富雄桜井誠樋口勝已

【目的】放射線治療において照射野は重要である。我々は治療ビ一ムを用いての照射野確認の試みと してレーザープロッター用フイルムを検討し、第1 8 回秋期学術大会で発表した。今回、対応できる 線量の拡大を目的に金属增感紙の材質、厚さを感度、画像特性について検討したので報告する。

【方法】金属板の厚みの設定 $10 \mathrm{HV} \mathrm{X}$ 線(三菱 ML15-M3), 照射野 $30 X 30 \mathrm{Cm}, S S D 100 \mathrm{Cm}$, 銅板 $0.1 \mathrm{~m}$ $\mathrm{m}$ から $1.8 \mathrm{~mm}$ まで変化させ、その厚み及び組合せの濃度との関係を求めた。前面のみでは銅及び鉛を、 両面では前面の結果より厚みを設定した。また、画像特性として特性曲線、R M S 粒状度、バーガー ファントムによる微細構造描出能、線量の增減による增感紙の視覚的評価を行なった。

【結果】金属板の厚みの設定 前面、後面に銅及び鉛の厚さと变化させ濃度測定の結果より、ハス羽 一、銅 $0.5+$ 銛 $1.0 \mathrm{~mm}$ 、銛 $1.0 \mathrm{~mm} 、$ 銅 $0.5 \mathrm{~mm}$ 、之蛍光增感紙GS、LT-2,FINE、の計 7 種について検討を進め た。画像特性 1 . 特性曲線 図 1 に金属增感紙の結果を示す。 2 . R M S 粒状度 図 2 に金属增 感紙の結果を示す。 3 . 微細構造描出能. 図 3 にその結果を示す。 4 . 線量と濃度及び描出の関係 表 1 に示す。

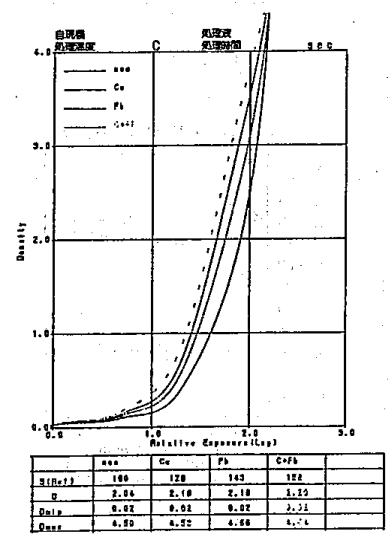

図 1

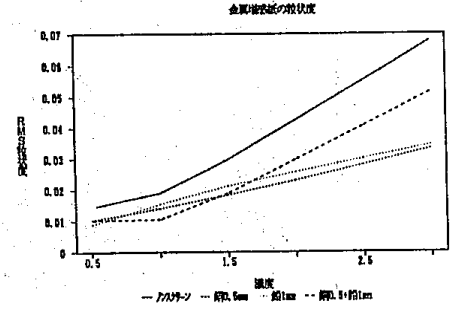

図 2

バーガファントムによる

敞絊满造描出能

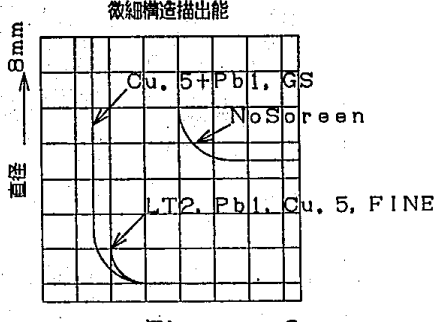

深さ $\longrightarrow 8 \mathrm{~mm}$

$\vec{Q} 3$

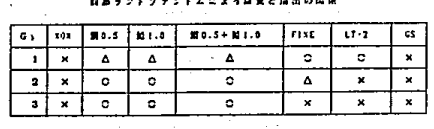

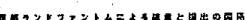

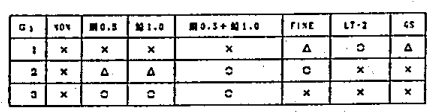

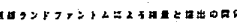

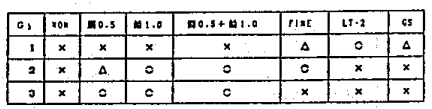

表 1

【考察】1．銅板は感度への寄与は少なく、鉊板の方がその寄与は大きい。それは金属よりでる二次 電子、二次 $\mathrm{x}$ 線の量が異なる為之思われる。2. 特性曲線から感度は100やり657と6倍強あるが、金 属增感紙は128から158ट低感度で、䖺光増感紙は272から657と高感度となった。これらは増感機序か 異なる為之考える。金属增感紙は大線量、蛍光增感紙は小線量に適応すると考える。3，RMS粒状度 で金属增感紙之虽光增感紙とに差がある。これは黒化の機序が異なる為と思わ机る。一方、GSは感度 に比へて值が大きくないのはスクリーン内の鉊による散乱線除去効果によるものと考えられる。4 . 微細楼造描出能では直径が小さくても深ければノンスクリーンを除く6種には大差はないが、直径が 大きくても浅ければ描出能に差が生じる。これは散乱線の寄与と平均諧調の值が関与していると思わ れる。5.ランドファントムの線量と視党的評価では部位による線量と壊度の関係では差はなく、至 適な增感紙の選択は識別可能な濃度域であるかによって決まると考える。しかし、ノンスクリーンの 3Gyでは識別可能な浱度ではあるが、像が不鮮鋭であるため識別は不可であった。

【結論】1．金属の材質では銅よりも鈶が增感効果は高い。2．金属增感紙は大線量の治療ビームに よる撮影に有用である。3，蛍光增感紙の併用で対応できる線量の幅が 6 倍強と広くなる。 